\title{
PERSPECTIVES ON THE BUDGET SURPLUS
}

\author{
Alan J. Auerbach \\ William G. Gale
}

Working Paper 7837

http://www.nber.org/papers/w7837

\section{NATIONAL BUREAU OF ECONOMIC RESEARCH 1050 Massachusetts Avenue \\ Cambridge, MA 02138 \\ August 2000}

We thank Ben Harris and Pete Kimball for research assistance, Kevin Hassett and Robert McIntyre for helpful discussions, and Ben Page and John Sturrock for providing and explaining the Congressional Budget Office's long-term forecast. All opinions are our own and should not be ascribed to any of the organizations with which we are affiliated.

(C) 2000 by Alan J. Auerbach and William G. Gale. All rights reserved. Short sections of text, not to exceed two paragraphs, may be quoted without explicit permission provided that full credit, including $\odot$ notice, is given to the source. 
Perspectives on the Budget Surplus

Alan J. Auerbach and William G. Gale

NBER Working Paper No. 7837

August 2000

\begin{abstract}
This paper provides alternative measures of federal budget surpluses over 10-year and longterm horizons. Official baseline budget forecasts are based on a series of statutory requirements that may be at variance with reasonable expectation. More plausible notions of current policy toward discretionary spending, taxes and retirement trust funds imply that surpluses over the next 10 years will be substantially smaller than the baseline forecasts indicate. Properly accounting for long-term imbalances in social security and the rest of the budget implies that, under plausible definitions of current policy, the federal government faces a long-term shortfall.
\end{abstract}

Alan J. Auerbach

Department of Economics

University of California, Berkeley

Berkeley, CA 94720

and NBER

Auerbach@econ.berkeley.edu
William G. Gale

The Brookings Institution

1775 Massachusetts Avenue, NW

Washington, DC 20036

Wgale@brook.edu 
After decades of deficits, the federal budget has recently turned to surplus, and projections suggest that under current policies the surplus will rise significantly during the next decade. The most recent Congressional Budget Office baseline forecast, released in July, 2000 (CBO 2000c), projects surpluses between $\$ 4.5$ trillion and $\$ 5.8$ trillion between 2001 and 2010. These are divided between (off-budget) surpluses in the social security trust fund of about $\$ 2.4$ billion and on-budget surpluses that range between $\$ 2.17$ trillion and $\$ 3.39$ trillion, depending on how discretionary spending is modeled (table 1).

Just as persistent budget deficits dominated policy discussions in the 1980s and early 1990s, choices regarding how to use the surplus will shape fiscal debates for years to come. Although leaders of both political parties agree that accruing social security trust fund balances should contribute to achieving that program's long-term financial viability, a fierce debate has emerged over the best way to use the remaining balances--the on-budget surpluses--with the choices being combinations of tax cuts, increased spending or debt repayment.

This debate is almost always framed in terms of the baseline forecast. Although it provides a common and visible benchmark, the baseline forecast does not provide sufficient information to assess the appropriateness of various policy options. First, the forecast is intended only to measure the implications of maintaining "current policy." But how one should project current policy into the future is not always obvious. The baseline forecasts project current policy subject to a variety of statutory requirements, which limit the scope of the forecast's underlying assumptions and time horizons and may be at variance with reasonable expectations. A more general concern in assessing the underlying fiscal situation is that alternative economic policies that have similar economic effects can nevertheless be 
portrayed in very different ways in government budget documents.

In light of these concerns, the goal of this paper is to provide alternative perspectives on the surplus. In section I, we focus on alternative budget measures within the 10-year horizon that is common in government budgeting. We examine alternative definitions of "current policy" towards discretionary spending, the alternative minimum tax, expiring tax provisions, and retirement trust funds. We show that reasonable variations in the definition of "current policy" generate widely varying 10-year on-budget results. Given what we view as the most plausible definition of current policy, the 10-year on-budget surplus available for new fiscal or tax policies is about $\$ 350$ billion. Although this remaining surplus is an impressive accomplishment, it is less than 10 percent of the projected overall surpluses during this period.

In section II, we show that even these short-term results can be misleading indicators of the underlying fiscal position of the federal government. Current surpluses exist largely because the government's accounting methods ignore the enormous accruing liabilities of future entitlement benefits. In the long term, when these liabilities begin to mature, the government faces the prospect of sizable deficits. It is difficult to see how intelligent policy choices can be made regarding the current surplus without an understanding of the longer-run fiscal situation.

Our calculations show that under plausible scenarios regarding current policy, the government faces a long-term fiscal imbalance. In the most plausible scenarios, an immediate and permanent increase in taxes or reduction in spending between 0.3 percent and 1.4 percent of GDP would be required to bring about permanent fiscal balance. The final section discusses some of the implications of these findings for the current fiscal debate. 


\section{Surpluses over the next 10 years}

\section{A. The baseline forecasts}

The Congressional Budget Office provides baseline projections under a set of pre-determined rules. Revenues, offsetting receipts, and mandatory spending are generally assumed to continue as they are currently structured in the law. ${ }^{1}$ Discretionary spending, however, poses special problems. Unlike mandatory programs, discretionary programs are subject to annual appropriations. As a result, "No consensus exists about how best to project the continuation of current policy for discretionary programs" (CBO 2000b, p. 79).

In the absence of consensus, $\mathrm{CBO}$ has recently chosen to present three scenarios. The capped baseline assumes that Congress complies with the statutory budget caps on discretionary spending through 2002 and then allows discretionary spending budget authority to grow at the rate of inflation thereafter. The freeze baseline holds discretionary spending budget authority at the nominal level enacted for the year 2000, plus any amounts already enacted for 2001. The inflated baseline allows discretionary spending budget authority to grow at the rate of inflation each year after 2000 .

All of the baselines refer to budget authority rather than outlays. CBO models actual outlays as a function of current and lagged budget authority. Table 2 shows the implications of these alternative

${ }^{1} \mathrm{~A}$ few exceptions are worth mentioning: for mandatory spending programs whose authority is slated to expire in the next decade, $\mathrm{CBO}$ is instructed to assume that the program will persist throughout the entire projection period, unless the program was enacted after 1997 and generates less than $\$ 50$ million in outlays. On the revenue side, scheduled expiration of excise taxes that are dedicated to trust funds are treated as if the expiration did not exist in the law. See Congressional Budget Office (2000b, p. 79). 
baselines for discretionary spending outlays. The inflated baseline generates the highest outlays in each year. The capped baseline generates lower outlays than the freeze baseline in 2001-5, but higher outlays in 2006-10. Total spending for the latter two scenarios is roughly equivalent over the 10-year period.

As shown in table 1, differences in discretionary spending across the three scenarios show up as somewhat larger differences in 10-year surplus totals. The differences in spending are compounded by differences in net interest payments associated with financing the programs. Surpluses under the inflated baseline are roughly $\$ 1.2$ trillion smaller than under the other baselines.

\section{B. Alternative views of current policy}

The view of current policy embodied in the baseline forecasts is clear, but it may not be the most plausible. In this section, we explore several alternative possibilities for current policy.

\section{(i) Discretionary Spending}

Discretionary spending totaled 6.3 percent of GDP in 1999. Under the capped, freeze and inflated baselines, discretionary spending would fall to 4.5 percent, 4.0 percent, and 5.2 percent of GDP, respectively, by 2010 (table 2). To meet the capped baseline, spending would have to fall in nominal terms between 2000 and 2002. It is reasonable to question whether any of these baselines represent a plausible view of what constitutes current policy toward discretionary spending.

The ratio of discretionary spending to GDP in 1999 was already the lowest since at least 1962 and likely well before that (figure 1). The baseline forecasts would cut such spending by an additional 
16 to 35 percent relative to GDP. Using the inflated baseline, suppose that all international spending were eliminated, and other discretionary spending were divided equally between domestic and defense, so that each was allocated 2.6 percent of GDP in 2010. For domestic spending, this would be the lowest percentage since 1962 (CBO 1999, p. 135). For defense, it would be the lowest percentage since before World War II (OMB 1999, tables 1.2 and 3.1). The capped and freeze baselines assume even lower levels for discretionary spending.

Although cuts in discretionary spending relative to GDP have occurred in the past, additional cuts may prove difficult. Much of the decline in the ratio of discretionary spending to GDP over the past 40 years, and virtually all of it since 1990, has occurred in defense spending (figure 2), where at least some downsizing was inevitable following the collapse of the Soviet Union. Domestic spending has also fallen from its peak as a share of GDP in 1979-81. For either category of spending, additional cuts are likely to prove difficult to make, especially with large surpluses and a booming economy.

Thus, as an alternative measure of current policy, we hold discretionary spending constant as a share of GDP. Figure 1 plots discretionary spending to GDP ratios for historical data, the three CBO baselines, and our additional scenario. Even under our scenario, discretionary spending would remain far below historical norms. Nevertheless, our assumption would reduce surpluses significantly over the 10-year horizon, relative to the inflated baseline (and by even more relative to the other baselines). Keeping the discretionary spending share of GDP constant would raise spending by $\$ 744$ billion between 2001 and 2010. Counting the added interest costs, the surplus would decline by $\$ 864$ billion 
relative to the inflated baseline. ${ }^{2}$ Thus, even modest adjustments to discretionary spending baselines that leave such spending well below its historical level nevertheless would cut significantly into projected onbudget surpluses.

\section{(ii) Tax Policy}

At least two issues concerning the definition of current tax policy merit further analysis: the individual alternative minimum tax (AMT) and expiring tax provisions. The AMT applies to a broader base than the regular income tax, but also provides a larger exemption and a lower top marginal tax rate. Because of its broader tax base definition, the AMT is most likely to apply to taxpayers who would have large deductions under the regular income tax that the AMT disallows. Any taxpayer whose AMT liability exceeds regular income tax must pay AMT.

The AMT is one of the most complex areas of individual tax law and, although strengthened considerably by the Tax Reform Act of 1986, still was intended to serve as a sort of backstop confronting the few taxpayers who push tax avoidance too aggressively. In practice, the AMT has remained largely confined to a small group of taxpayers; in 2000, an estimated 1.3 percent of taxpayers will be on the AMT. ${ }^{3}$

However, for a variety of reasons, particularly the fact that the AMT exemption is not indexed

${ }^{2}$ We calculate interest costs by assuming the rate of interest is the average of the three-month Treasury Bill and the 10-year Treasury Bond rates (CBO 2000c, table D-2). We assume that half of expenditures in a given year accrue interest costs during that year, and all of the expenditures in a given year accrue interest costs in subsequent years.

${ }^{3}$ All information on the AMT is taken from Rebelein and Tempalski (2000). 
for inflation, the proportion of taxpayers on the AMT is projected to rise dramatically over the next decade. Under current law, that proportion is predicted to rise to 6 percent in 2005 and over 15 percent in 2010. In the latter year, a third of taxpayers with income between $\$ 75,000$ and $\$ 200,000$ and almost two-thirds of taxpayers with income between $\$ 200,000$ and $\$ 500,000$ would be on the AMT.

It seems unlikely that this pattern will be allowed to occur. It would represent a historic shift in the role of the AMT, raising the proportion of taxpayers who face AMT by a factor of 10 . It would be fought fiercely by middle- and high-income groups. Indeed, the problem has already received significant attention, even though only a small portion of taxpayers currently face the AMT.

For all of these reasons, we believe that "current policy" would be better represented by incorporating an adjustment that would keep the proportion of taxpayers affected by the AMT at about 1.3 percent. Unfortunately, we do not have revenue estimates of this policy change. Estimates do exist, however, for policies that index the parameters of the AMT for inflation. ${ }^{4}$ Under this policy, the proportion of taxpayers facing the AMT would rise to 1.9 percent in 2010, which is clearly far below the 15.7 percent implied by current law. The lost tax revenue from this policy would be $\$ 83$ billion over the next 10 years. Counting the added interest, we estimate the net cost would be $\$ 94$ billion.

The second issue relates to expiring tax provisions. For all taxes other than excise taxes dedicated to trust funds, $\mathrm{CBO}$ assumes that legislated expirations occur as scheduled. A significant number of provisions are projected to expire over the next 10 years, including one in 2000, fourteen in

${ }^{4}$ These parameters include the exemption, the taxable income level at which the 28 percent AMT bracket begins, and the income level at which AMT exemption phase out begins. 
2001, and seven between 2002 and 2008. ${ }^{5}$ In the past, these provisions were typically extended another few years each time the expiration dates approached. In light of this practice, a reasonable view of the definition of current policy is that these so-called "extenders" will be extended further. Extending all of these provisions--except the one relating to AMT, the need for which would be obviated by our previous assumed policy adjustment--through the 10-year horizon would cost, on net, $\$ 52$ billion in lost revenues (CBO 2000a, table 3-12) plus an additional \$9 billion in interest costs.

\section{(iii) Retirement Trust Funds}

As noted above, there is a general agreement among political leaders of both parties that social security trust fund balances should not be used to support current spending (other than social security benefits) or tax cuts. Rather, it should be preserved to help satisfy current and future social security obligations. The same issue arises with respect to other retirement trust funds in the budget.

Specifically, trust funds for Medicare (Part A) and government military and civilian employee pensions are projected to run surpluses totaling $\$ 802$ billion over the next 10 years. The Medicare (part A) trust fund accounts for $\$ 360$ billion, with military and civilian pension reserves accounting the remaining $\$ 442$ billion (CBO, 2000c, table 1-12). Under current procedures, these surpluses are a component of the on-budget surplus.

The key issue is whether, in the wake of the recent agreement not to raid social security trust funds, it makes sense to extend the same treatment to the trust funds for Medicare and government

${ }^{5}$ In the last group, four would actually raise revenue if extended (for example, the luxury tax on passenger vehicles). 
pensions. Like social security, the Medicare and government pension trust funds used to be run on a pay-as-you-go basis but are now being partially funded, as evidenced by the accruing surpluses. All of these trust funds represent current accumulations intended to provide retirement benefits to future workers. Thus, there is a sound economic case for comparable budget treatment.

Recently, Democratic presidential nominee Al Gore proposed to remove the Medicare trust fund as a possible financing source of additional (non-Medicare) spending or reductions in taxes (Connolly 2000, Balz and Connolly 2000). Shortly thereafter, the House of Representatives approved by a vote 420-2 a measuring promising not to use the Medicare trust fund to finance other programs or tax cuts (Eilperin 2000). It is also worth noting that many states already separate their pension reserves from funds available for tax cuts and other spending. Thus, it is plausible that current policy is evolving toward the view that these trust funds should not be allocated to other spending or tax programs.

\section{(iv) Overall Implications}

Clearly, there are many dimensions to views of what could plausibly constitute "current policy." In table 3, we combine the earlier results to understand the implications of different definitions. The first three entries in the first column simply replicate the 10-year on-budget surplus figures from table 1 for the three baseline scenarios developed by CBO. The last entry in the first column shows that allowing discretionary spending to grow with GDP reduces the 10-year on-budget surplus to $\$ 1,309$ billion. In contrast, under the capped baseline the surplus would be $\$ 2$ trillion higher. Thus, assumptions about discretionary spending are crucial inputs into the 10-year forecast.

The second column shows the impact of adjusting for the AMT and the expiring tax provisions. 
If discretionary spending is allowed to grow with GDP and the tax adjustments are made, the net result is a 10-year on-budget surplus of $\$ 1,155$ billion. The third column shows the effects of moving the nonsocial security retirement trust funds out of the on-budget calculations. This reduces the 10-year onbudget surplus to just over $\$ 500$ billion if the ratio of discretionary spending to GDP is held constant. If all three sets of adjustments are made--for discretionary spending, taxes and the retirement trust funds-the 10-year surplus is $\$ 353$ billion.

Thus, the estimates span the range between a surplus of $\$ 3.4$ trillion and $\$ 350$ billion, a difference of more than $\$ 3$ trillion. This range represents about 2.3 percent of projected GDP over the decade. All of these estimates abstract from economic uncertainty, which should serve as a caveat to all budget forecasts. One reason why is that the surplus or deficit is a residual, the difference between revenues and outlays, and relatively small changes in the economy--which is itself difficult to predict--or in revenues or spending relative to the economy, can have relatively large impacts on the surplus. Also, changes in government's fiscal position at one point tend to build on themselves over time. That is, short-run mis-estimates are typically amplified as the forecast horizon lengthens. For example, an increase in revenues raises current surpluses, which reduces interest costs and therefore raises future surpluses.

\section{Tax cuts}

As noted above, current and projected surpluses have created serious consideration of largescale tax cuts. Republican presidential nominee George W. Bush has proposed a series of tax policy changes, including increases in the child tax credit, a new taxable income bracket with a rate of 10 
percent, a phased-in reduction of individual income tax rates that would reduce the 36 and 39.6 percent rates to 33 percent and the 31 and 28 percent rates to 25 percent, a second-earner deduction, a charitable deduction for taxpayers who do not itemize, education IRAs, phased-in reduction and repeal of estate taxes, and other changes.

The Joint Committee on Taxation (JCT, 2000a, 2000b) estimates that these proposals would reduce revenues by $\$ 1,320$ billion between 2001 and 2010 (table 4). Several aspects of this estimate should be noted. First, it does not include any adjustment of the AMT. If the tax cut were implemented, many more people would face AMT. Reducing the AMT to keep the proportion of taxpayers on the AMT at the same levels as in the indexing option discussed above would cost more in revenues with a regular income tax cut than without. Second, the JCT estimate covers only the first 9 years of the tax cut, not 10, because the cut would not take effect until 2002. Third, the JCT estimate does not include any added interest costs. We estimate interest costs of $\$ 225$ billion, and the total cost (excluding any AMT adjustment) at $\$ 1.545$ trillion over the first 9 years of the tax cut. Finally, the JCT estimates were calculated relative to an earlier CBO baseline with lower aggregate revenues. Using the more recent baseline almost surely would raise the cost of the tax cut substantially, because rates reductions would be applied to higher levels of income.

Combined with the various measures of current policy noted in table 3, Governor Bush's tax cut (as estimated by JCT) would result in an on-budget surplus of up to $\$ 1.84$ trillion under the most optimistic measure of current policy, to a deficit of $\$ 1.19$ trillion under the least optimistic.

\section{The long-term fiscal imbalance}


In this section, we turn to estimates of the fiscal status of the government over much longer horizons. Despite the added uncertainty inherent in such estimates, extending the horizon is particularly important to account for the looming growth in entitlement programs driven by an aging population and rapidly rising medical care expenditures. Moreover, the presence of uncertainty should not lead us to ignore long-term issues. Indeed, under reasonable assumptions, the potentially serious consequences of a relatively bad long-term outcome should spur a precautionary policy response (Auerbach and Hassett 2000).

\section{A. Methodology}

Our analysis relies on the most recent long-term budget forecasts produced by CBO, which extend its 10-year forecast through the year $2070 .^{6}$ After the year 2070, we assume that all revenue and non-interest expenditures remain constant as a share of GDP at their 2070 levels.

Between the end of the 10-year horizon and the year 2070, social security and Medicare expenditures are assumed to follow the intermediate projections of the trustees, adjusted for differences between the economic forecasts of CBO and the Social Security Administration. Medicaid is projected using the same basic approach as that used for Medicare, incorporating a key — and probably overly optimistic - assumption that the growth rate of aggregate medical spending per enrollee slows gradually

${ }^{6} \mathrm{As} \mathrm{CBO}$ has not yet issued long-term forecasts consistent with its most recent 10 -year budget forecast, we update the previous long-term CBO forecast (from late 1999) in the following manner. For years through 2010, we incorporate the projected changes in revenues and outlays (excluding debt service). For years after 2010, we assume that the changes in revenue and non-interest outlays are equal as a share of GDP to the changes projected for 2010. 
to match that of average wages by 2020 . These assumptions imply that social security expenditures are projected to rise from about 4 percent of GDP in 2000 to 6 percent by 2050. Medicare and Medicaid are projected to rise from about 4 percent of GDP in 2000 to 10 percent in 2050.

Discretionary spending, federal consumption of goods and services, and all other government programs, with the exception of net interest, are assumed to grow with GDP after 2010. Tax revenues are a constant share of GDP, except for supplementary medical insurance premiums collected for Medicare, which grow relative to GDP.

Using these assumptions, we update calculations based on a methodology developed in Auerbach (1994) and applied there and in Auerbach (1997) and Auerbach and Gale (1999a, 1999b). The technique solves for the "fiscal gap"--the size of the permanent increase in taxes or reductions in non-interest expenditures (as a constant share of GDP) that would be required to satisfy the constraint that the current national debt equal the present value of future primary surpluses. The primary surplus is revenues minus all expenditures other than net interest. The same result would follow from assuming that the debt/GDP ratio eventually returns to its current level.

In the past, $\mathrm{CBO}$ has undertaken a similar calculation by measuring the size of the immediate and permanent revenue increase or spending cut that would be necessary to result in a debt-to-GDP ratio in 2070 equal to today's ratio. The cutoff at 2070 is arbitrary, however. Estimates using a longer horizon will be larger since the budget is projected to be substantially in deficit during the years approaching 2070 (and those that follow). That is, the picture between now and 2070 understates the magnitude of the long-term problem. 


\section{B. Estimates}

Table 5 shows that the alternative spending and tax policies discussed above can have a huge effect on the long-term fiscal status of the federal government, if these policies establish levels of spending or taxes that are preserved (relative to GDP) after 2010. For example, using the CBO capped baseline, the government has a negative fiscal gap, i.e., is in surplus, over the next 70 years (at 1.41 percent of GDP), and even the permanent fiscal gap is negative, although less so ( 0.44 percent of GDP). However, using the inflated baseline for the next 10 years raises the gap by roughly $3 / 4$ of a percent of GDP over either horizon. Thus, the permanent fiscal gap would become positive, on the order of 0.31 percent. Allowing discretionary spending outlays to remain constant as a share of GDP over the next 10 years raises the fiscal gap further, to 0.28 percent of GDP over the next 70 years and 1.36 percent on a permanent basis.

Allowing the tax cut of the magnitude advocated by Governor Bush (as estimated by JCT) would raise each of these figures by about 1.5 percent of GDP over both horizons. Thus, if discretionary spending stayed constant as a fraction of GDP and the tax cut were enacted the permanent fiscal gap would be 2.89 percent. That is, to restore fiscal balance would require an immediate and permanent cut in spending or increase in taxes equal to 2.89 percent of GDP, or about $\$ 280$ billion per year in today's economy. The annual cost would be even higher, of course, if these compensating measures were not enacted immediately.

In light of the recent political pressure to raise spending and/or cut taxes, it seems unlikely that there will be any immediate action to reduce the fiscal gap. But delaying the implementation of needed tax increases or spending cuts will simply raise the required fiscal correction at the time of 
implementation. For example, with discretionary spending constant as a fraction of GDP, a 10-year delay would raise the gap from 1.36 percent to 1.61 percent of GDP (not shown). With a tax cut as well, the gap after a 10-year delay would be 3.25 percent of GDP, rather than 2.89 percent (not shown).

These estimated fiscal gaps are intended only to indicate the magnitude of the long-term budgetary imbalance. Our estimates, for example, do not take into account the macroeconomic effects of policy changes. One might expect that, by omitting feedback effects, we would overstate the needed policy changes, by ignoring the salutary impact of deficit reduction on the economy. However, this need not be the case. Working in the opposite direction is the fact that we start from alternative initial baseline projections that do not incorporate the negative economic consequences of growing long-run deficits. Thus, our estimates of what it would take to close the long-run gap incorporate neither the macroeconomic effects of the projected rise in deficits nor those of adopting policies to undo this rise.

In contrast, CBO's earlier estimates incorporates both such feedback effects, which is the source of the small difference between CBO estimates over the period through 2070 and the estimates in Auerbach and Gale (1999a). The fact that our estimate of the fiscal gap was lower than CBO's means that our omission of feedback effects (in both the baseline and in reaction to policy) leads to a net understatement of the size of the long-run gap through 2070 and presumably, over the longer horizon as well.

Moreover, neither our calculations, nor those of $\mathrm{CBO}$, take account of the negative macroeconomic consequences of labor supply and savings responses to the future marginal tax rate increases that may be needed to close the fiscal gap. As this gap and the associated future tax increases 
would be substantially increased by an immediate tax cut, any beneficial growth effects of these tax cuts would have to be measured against the offsetting negative growth effects of the tax increased needed in compensation. Together, the two factors suggest that adding feedback effects is likely to make the net impact of tax cuts on fiscal balance look worse, not better. ${ }^{7}$

\section{Conclusions}

The virtually exclusive emphasis given to baseline 10-year budget projections in current fiscal policy debates is inappropriate. The baseline forecast suggests the availability of trillions of dollars for tax cuts or new spending, but is based on a particular set of views of what constitutes current policy. We find that more plausible notions of current policy regarding discretionary spending, the alternative minimum tax, and expiring tax provisions, and the appropriate use of government trust funds reduce the 10-year surplus available for tax cuts or new initiatives to just over $\$ 350$ billion.

More importantly, focusing on the 10-year horizon omits crucial elements of the long-term fiscal picture. Properly accounting for long-term imbalances in social security and in the rest of the budget implies that, under the most plausible definitions of current policy that we examine, the federal government faces a long-term financial shortfall.

These findings suggest some useful lessons to apply to the current debate about how to allocate

${ }^{7}$ The possible feedback effects of spending programs are also omitted. For example, to the extent that spending on education or infrastructure raises future productivity, the needed tax increases or spending cuts would be reduced somewhat. However, to take proper account of these effects, one would also need to begin from a baseline that incorporated the correspondingly negative effects of projected cuts in discretionary spending. As with deficits, these two feedback effects would work in opposite directions, and the net effect is not clear. 
the surplus. First, despite the recent strong improvement in the government's fiscal position, there is still a long-term imbalance. This imbalance is a "future" problem only insofar as our chosen budget accounting rules ignore the existence of liabilities already accrued.

Second, given this long-term imbalance, the fiscal climate may be more troubling currently than in previous years. The short-term surplus and the decline in the long-term fiscal gap are no doubt improvements. But fiscal discipline may be especially difficult to impose now. In the 1980s and early 1990s, when the country faced short-term and long-term deficits, the former helped focus attention in a way that also helped reduce the latter. Currently, the country faces the same trade-off between current and future generations as in earlier decades, and we still face a long-term shortfall, but most of the policy discussion focuses on ways to use current surpluses--via new spending or tax cuts--that would exacerbate the long-term situation. Thus, as we have argued in our earlier papers, the current focus on how to use the current surplus is misplaced, once one recognizes how misleading the surplus calculation is. 


\section{References}

Auerbach, Alan J. 1994. "The U.S. Fiscal Problem: Where We Are, How We Got Here, and Where We're Going," in Stanley Fischer and Julio Rotemberg, eds. NBER Macroeconomics Journal,. Cambridge, MA.

Auerbach, Alan J. 1997. "Quantifying the Current U.S. Fiscal Imbalance.” National Tax Journal, 50:3: 387-98.

Auerbach, Alan J. and William G. Gale. 1999a. "Does the Budget Surplus Justify a Large-Scale Tax Cut?" Tax Notes, March 22: 1827-1850.

Auerbach, Alan J. and William G. Gale. 1999b. "Does the Budget Surplus Justify Big Tax Cuts?: Updates and Extensions." Tax Notes, October 18: 369-376.

Auerbach, Alan J. and Kevin A. Hassett. 2000. "Uncertainty and Design of Long-Run Fiscal Policy," in Alan J. Auerbach and Ronald D. Lee, eds. Demographic Change and Fiscal Policy. Cambridge, UK: Cambridge University Press, forthcoming.

Balz, Dan and Ceci Connolly. 2000. "Gore to Propose Medicare 'Lockbox.'” Washington Post, June 8, A1.

Connolly, Ceci. 2000. "Gore Outlines Several Uses for Surplus.” Washington Post, June 14, A1.

Congressional Budget Office. 1999. The Economic and Budget Outlook: Fiscal Years 2000-2009. Washington, D.C.: U.S. Government Printing Office, January.

Congressional Budget Office. 2000a. The Budget and Economic Outlook: Fiscal Years 2001-2010. Washington, D.C.: U.S. Government Printing Office, January.

Congressional Budget Office. 2000b. An Analysis of the President's Budgetary Proposals for Fiscal Year 2001. Washington, D.C.: U.S. Government Printing Office, April.

Congressional Budget Office. 2000c. The Budget and Economic Outlook: An Update. Washington, D. C.: U.S. Government Printing Office, July.

Eilperin, Juliet. 2000. "House Backs Medicare Plan Similar to Gore 'Lockbox," Washington Post, June 21, A8.

Joint Committee on Taxation. 2000a. "Paull Letter to Archer on Revenue Estimates of Bush Tax 
Reduction Proposal." May 1.

Joint Committee on Taxation. 2000b. "Estimated Revenue Effects of Various Provisions Described as the 'George W. Bush Tax Reduction Proposal.'” May 3.

Rebelein, Bob and Jerry Tempalski. 2000. "Who Pays the Individual AMT?” Office of Tax Analysis, June, 2000.

U.S. Office of Management and Budget. 1999. Budget for Fiscal Year 2000, Historical Tables. Washington, D.C.: U.S. Government Printing Office.

U.S. Social Security Administration, Board of Trustees of the Federal Old-Age and Survivors Insurance and Disability Insurance Trust Funds. 2000. 2000 Annual Report of the Board of Trustees of the Federal Old-Age and Survivors Insurance Trust Fund and the Federal Disability Insurance Trust Fund. Washington, D.C., March 30. 
Table 1

CBO Baseline Budget Surplus Projections, 2001-2010

(\$ Billions)

\begin{tabular}{|c|c|c|c|}
\hline Baseline: & On-Budget & Off-Budget & Total \\
\hline Capped & 3,387 & 2,388 & 5,774 \\
\hline Freeze & 3,349 & 2,395 & 5,744 \\
\hline Inflated & 2,173 & 2,388 & 4,561 \\
\hline
\end{tabular}


Table 2

CBO Baseline Budget Projection:

Discretionary Spending in Nominal Dollars and as a Percent of GDP

$\underline{\text { Baseline }}$

Capped

Discretionary Spending

Percent of GDP

Freeze

Discretionary Spending

Percent of GDP

Inflated

Discretionary Spending

Percent of GDP

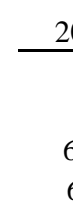

$\begin{array}{llll}2000 & 2001 & 2002 & 200\end{array}$

608

$\begin{array}{rr}608 & 579 \\ 6.2 & 5.6\end{array}$

608

6.2

625

6.1

627

627
5.8

628

5.5

623

625

5.1

622

4.8

$608 \quad 638$

$6.2 \quad 6.2$

$656 \quad 676$

693

$713 \quad 728$

$\begin{array}{lllll}6.1 & 6.0 & 5.9 & 5.8 & 5.6\end{array}$

744
5.5

765
5.4

2008

2009

2010

Total

2001-2010

Source: Congressional Budget Office. July 2000. The Budget and Economic Outlook: An Update. Tables 1-8, 2-3.

Nominal spending is given in billions of dollars per fiscal year. 
Table 3

On-Budget Surpluses, 2001-2010, Under Alternative Views of Current Policy (\$ Billions)

Include Tax Adjustments

Remove Retirement Trust Funds

From On-Budget Totals

Discretionary Spending Path

Capped Baseline

Freeze Baseline

Inflated Baseline

Constant DS/GDP

Source: Authors' calculations.
No $\quad$ Yes $\quad$ No $\quad$ Yes

No No Yes Yes

\begin{tabular}{lrrr}
\hline 3,387 & 3,233 & 2,585 & 2,431 \\
3,349 & 3,195 & 2,547 & 2,393 \\
2,173 & 2,019 & 1,371 & 1,217 \\
1,309 & 1,155 & 507 & 353
\end{tabular}


Table 4

Budget Effects of Tax Cuts

\begin{tabular}{|c|c|c|c|c|c|c|c|c|c|c|c|}
\hline Budget Effect & 2001 & 2002 & 2003 & 2004 & 2005 & 2006 & 2007 & 2008 & 2009 & 2010 & $\begin{array}{c}\text { Total } \\
2001-2010 \\
\end{array}$ \\
\hline JCT Estimated Revenu & 0 & 21.1 & 57.4 & 88.9 & 125.5 & 167.1 & 193.2 & 210 & 224.5 & 232.9 & $1,320.6$ \\
\hline Added Interest Costs & 0.0 & 0.6 & 2.7 & 6.5 & 12.1 & 19.8 & 29.2 & 39.8 & 51.2 & 63.2 & 225.0 \\
\hline Total Costs & 0.0 & 21.7 & 60.1 & 95.4 & 137.6 & 186.9 & 222.4 & 249.8 & 275.7 & 296.1 & $1,545.6$ \\
\hline
\end{tabular}

Source: Joint Committee on Taxation and authors' calculations. 
Table 5

Estimates of Long-Term Fiscal Imbalances as a Percent of GDP

Spending and Tax Assumptions

CBO Capped Baseline (through 2002)

CBO Inflated Baseline

Constant DS/GDP

Capped Baseline + Tax Cut

Inflated Baseline + Tax Cut

Constant DS/GDP + Tax Cut
Through 2070

$-1.41$

$-0.67$

0.28

0.06

0.81

1.75
Permanent

$-0.44$

0.31

1.36

1.09

1.84

2.89

Source: Authors' calculations. 
Figure 1

Discretionary Spending as a Percentage of GDP, 1962-2010

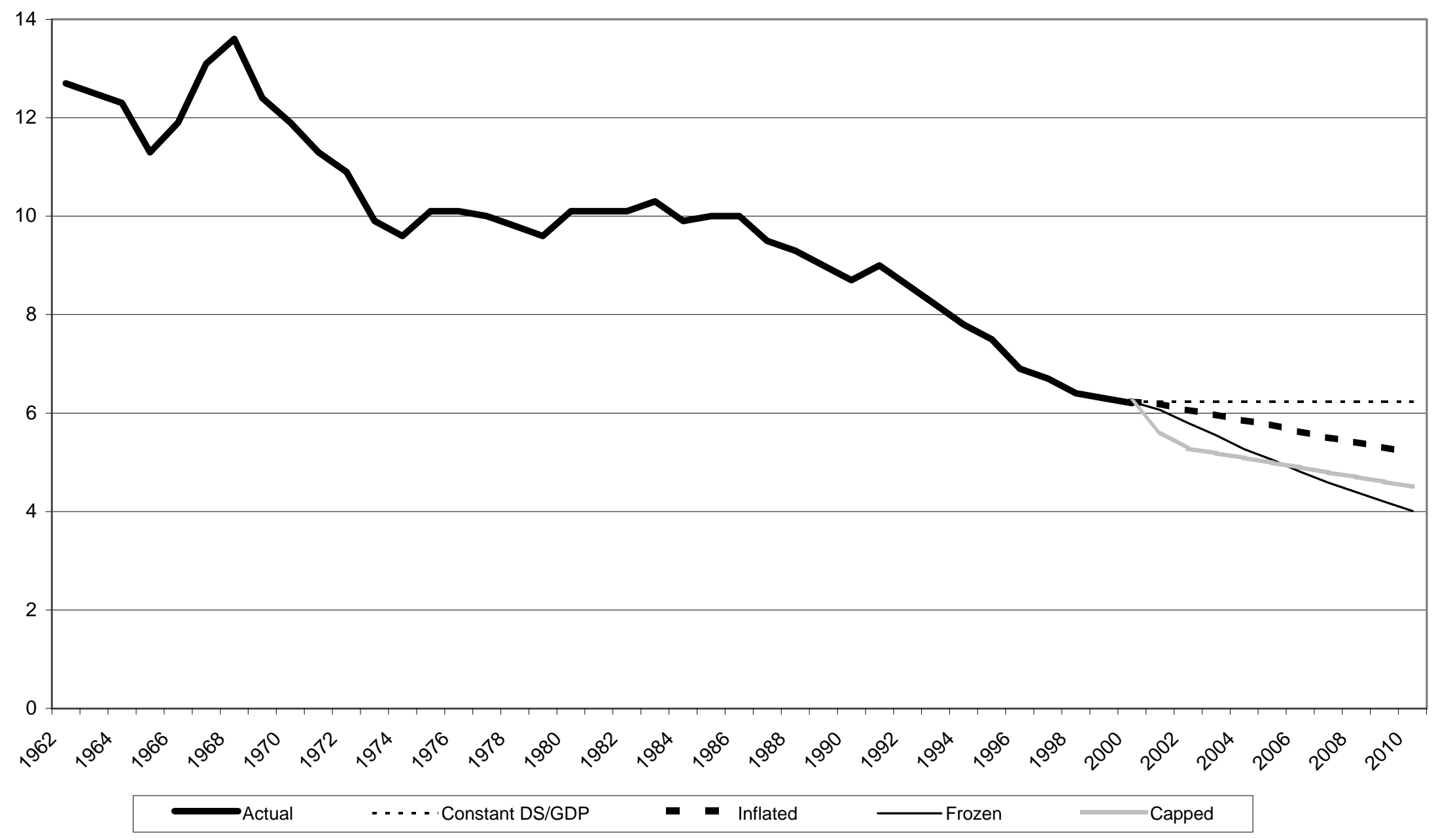

Source: Congressional Budget Office. 2000. An Analysis of the President's Budgetary Proposals for Fiscal Year 2001.; Congressional Budget Office. 2000. The Budget and Economic Outlook, Fscal Years 2001-2010; and authors' calculations. 
Figure 2

Components of Discretionary Spending as a Percent of GDP, 1962-1999

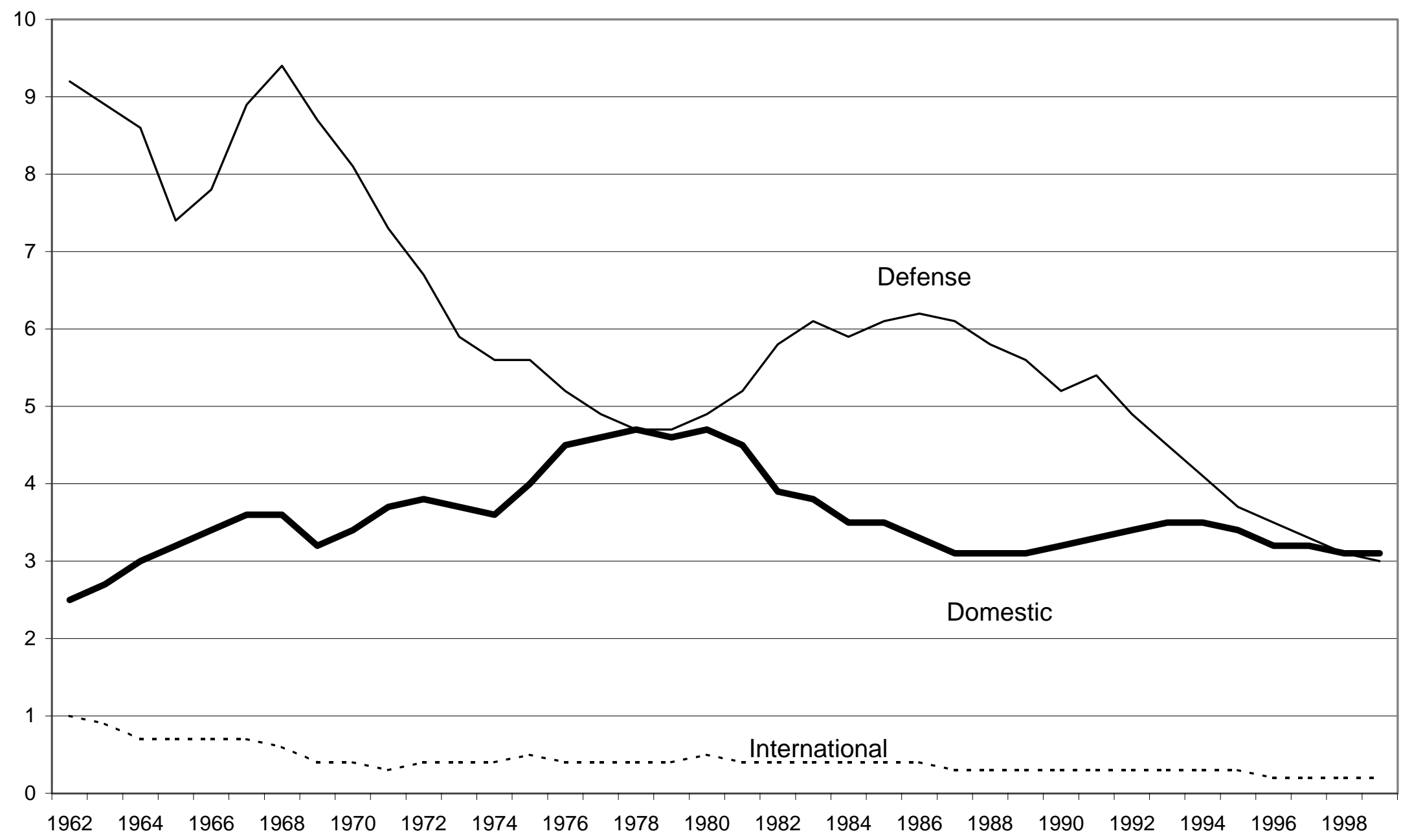

Source: Congressional Budget Office. 2000. The Budget and Economic Outlook: Fiscal Years 2001-2010, Tables E-10 and E-11. 